\title{
Protective immunity against lethal HSV-1 challenge in mice by nucleic acid-based immunisation with herpes simplex virus type-1 genes specifying glycoproteins $\mathrm{gB}$ and $\mathrm{gD}$
}

\author{
ABOLGHASEM BAGHIAN, VLADIMIR N. CHOULJENKO, OSWALD D'AUVERGNE*, \\ MARK J. NEWMAN†t, SALMAN BAGHIAN and KONSTANTIN G. KOUSOULAS
}

Department of Veterinary Microbiology and Parasitology, School of Veterinary Medicine, Louisiana State University, Baton Rouge, LA 70803, *Department of Biological Sciences, Southern University, Baton Rouge, LA 70813 and †Vaxcel, Norcross, GA, USA

\begin{abstract}
DNA-based vaccines were employed to assess protective immunity against herpes simplex virus in experimental infections of hairless (strain SKH1) and BALB/c mice. Mice were vaccinated with plasmids containing the herpes simplex virus type-1 (HSV-1) glycoprotein B (gB) or D (gD) genes under the human cytomegalovirus immediate-early promoter control. Vaccines were injected intramuscularly (i.m.) or intraperitoneally (i.p.) as purified DNA alone or as formulations supplemented with different non-ionic block copolymers. Antibody responses were assessed by immunofluorescence and radioimmunoprecipitation assays. Mice inoculated with either $\mathrm{gB}$ or gD plasmid, alone or with non-ionic block copolymers CRL 1029 and CRL 1190, produced high levels of antibodies specific for $\mathrm{gB}$ or $\mathrm{gD}$. Three weeks after the last vaccination, mice were challenged with a clinical HSV-1 isolate (ABGK-1) by inoculation of a shaved and subsequently scarified area between the third and fourth lumbar vertebrae. Mice immunised with either gD or gB plasmid alone or mixed with copolymers were protected against lethal HSV-1 challenge when immunisation was performed via the i.m. route. Immunisations given via the i.p. route induced humoral responses in some mice and protected the animals against lethal $\mathrm{HSV}-1$ challenge only when the formulations contained copolymers. The BALB/c mouse model was shown to be as good a model as the hairless mouse model.
\end{abstract}

\section{Introduction}

Herpesviruses are the causative agents or co-factors of important human and animal diseases, including certain cancers. They possess the unique ability to remain latent and can be reactivated causing severe or chronic diseases [1]. Conventional methods of generating protective immunity against infectious agents have relied on the use of attenuated or killed viruses or recombinant components of the viruses. All of these approaches have limitations that reduce their usefulness as vaccines. For example, attenuated pathogens have inherent risks that may limit their use in man [2]. Vaccines based on killed viruses can induce strong

Received 11 June 2001; revised version received 3 Oct. 2001; accepted 30 Oct. 2001.

Corresponding author: Dr A. Baghian.

†Present address: Epimmune, San Diego, CA, USA. antibody responses; however, generally, they are unable to induce MHC class I-restricted responses. As the incidence of herpes continues to increase in the population, and as new strains of the virus resistant to chemotherapy continue to emerge, so does the need for a safe and effective vaccine.

At least 11 virus-specified glycoproteins are found on the surface of the herpes simplex virus (HSV) virion and in the plasma membranes of HSV-infected cells and serve as important targets of humoral and cellular immunity [3-5]. They are designated as $\mathrm{gB}, \mathrm{gC}, \mathrm{gD}$, $\mathrm{gE}, \mathrm{gG}, \mathrm{gH} \mathrm{gI}, \mathrm{gJ}, \mathrm{gK}, \mathrm{gL}$ and $\mathrm{gM}$. Viral glycoproteins $\mathrm{gB}, \mathrm{gD}$ and $\mathrm{gC}$, the most abundant proteins, are the primary elements of vaccine efforts to combat HSV infections. Recombinant baculoviruses were used to express $\mathrm{gB}$ and $\mathrm{gD}$. When these glycoproteins were used as vaccines, they induced high levels of protective immunity against lethal viral challenge in BALB/c 
mice [6,7]. Immunopurified $\mathrm{gD}$ and $\mathrm{gB}$ and truncated forms of these glycoproteins have been used to induce protective immune responses in mice and other animal models [8-13].

An observation in 1990 showed that direct introduction of plasmid DNA encoding specific antigens can be taken up by muscle cells and be expressed [14]. DNA vaccination against various pathogens, including human immunodeficiency virus (HIV) $[15,16]$, bovine herpes virus [17], influenza [18-20], rabies virus [21], hepatitis B virus [22] and malaria [23] have been evaluated as vaccines in several animal models. Vaccination of mice via intranasal and intramuscular routes with plasmid DNA expressing HSV-1 gB induced protection against HSV-1 challenge through a vaginal route of infection [24]. Protection of mice or guinea-pigs against systemic or vaginal infections with HSV-1 or HSV-2 viruses by DNA vaccination with HSV-1 or HSV-2 $\mathrm{gB}$ or $\mathrm{gD}$ genes has been reported $[25,26]$. Similarly, it was shown that mice immunised intramuscularly (i.m.) with plasmid DNA encoding equine herpesvirus 1 glycoprotein D (EHV-1 gD) were protected against intranasal challenge with EHV-1 [27]. Intraperitoneal vaccinations have not been used frequently to assess vaccination potential. In one case, mice vaccinated intraperitoneally (i.p.) with DNA plasmids coding for the Coccidioides immitis Ag2 were protected against infectious challenge with $C$. immitis [28].

Non-ionic block copolymers comprise a single chain of hydrophobic polyoxypropylene (POP) sandwiched between two hydrophilic chains of polyoxyethylene (POE). Copolymers have been used as vaccine adjuvants and as anti-infective agents for the treatment of established bacterial and viral infections in formulations based on protein antigens [29-31]. The adjuvant activity of non-ionic block copolymers is influenced by both size and POE content. As the size of the POP core is increased, so is the adjuvant activity of the copolymer, and peak activity is achieved with copolymers with POP cores that are $12-15 \mathrm{kDa}$. Maximal adjuvant activity is also correlated with low POE content, $5-10 \%$ is optimal [29-31].

Induction of humoral immune responses generated by DNA-based vaccination with plasmids expressing $\mathrm{gB}$ and $\mathrm{gD}$ genes injected i.p. or i.m. was investigated in this study. The vaccination was performed with or without non-ionic block copolymers. The protective efficacy of these vaccines, with or without copolymers, was evaluated by challenging the mice with a lethal dose of HSV-1.

\section{Materials and methods}

Virus, cells and media

HSV-1 ABGK-1 was isolated from a cold sore lesion of a male individual who was otherwise healthy. The virus was propagated in African green monkey kidney (Vero) cells and viral stocks were made after the third passage. Vero cells were propagated in Dulbecco's modification of Eagle's medium (DMEM) supplemented with heat-inactivated fetal bovine serum $10 \%$. The virus was confirmed as HSV-1 by indirect immunofluorescence with an HSV-1 specific monoclonal antibody (MAb).

\section{Mice}

Female BALB/c and hairless (strain SKH-1) mice were purchased from Harlan Sprague-Dawley (Indianapolis, IN, USA). The hairless mouse is a good model for induction of zosteri form lesions by HSV-1; otherwise, no immunological deficiency has been associated with this strain of mouse. Mice used in this study were typically 8-12 weeks old and were bred in the Laboratory Animal Research Facility of the School of Veterinary Medicine, Louisiana State University.

\section{Plasmid constructs}

A 3.7-kb HindIII DNA fragment containing the $\mathrm{gB}$ gene [32] and a 1.8-kb HindIII DNA fragment containing the $\mathrm{gD}$ gene [33] were cloned into plasmid pcDNA 3.1 placing the genes under the transcriptional control of the human cytomegalovirus (CMV) immediate-early promoter. Recombinant plasmids were purified by $\mathrm{CsCl}$ gradient separation, concentrated by ethanol precipitation, dissolved in distilled water and stored at $-20^{\circ} \mathrm{C}$. The concentration and purity of DNA were determined by spectrophotometric methods and by agarose gel electrophoresis, respectively.

\section{Synthesis of non-ionic block copolymers}

Copolymers were produced by ring opening addition polymerisation with two or more monomers, added in predetermined sequences and amounts. The high mol. wt non-ionic block copolymers used for these studies were synthesised from propylene oxide and ethylene oxide with propylene glycol as the initiator and a proprietary base catalysed process. Copolymers were produced based on 11- (CRL 1029) and 15- (CRL 1190) $\mathrm{kDa}$ POP internal cores with POE 5\% end blocks, POE-POP-POE.

\section{Transient expression of $g B$ and $g D$}

Vero cells were transfected with $\mathrm{gB}$ plasmid constructs by a procedure based on a modification of the calcium phosphate method [32,34]. Briefly, Vero cells were grown to $50-70 \%$ confluence in $25-\mathrm{cm}^{2}$ tissue-culture flasks. Purified plasmid DNA ( $15 \mu \mathrm{g})$ was suspended in $0.5 \mathrm{ml}$ of double-distilled water containing $250 \mathrm{~mm}$ $\mathrm{CaCl}_{2}$. Subsequently, $0.5 \mathrm{ml}$ of a solution consisting of $2 \times$ BBS - $50 \mathrm{~mm}$ BES (N, N-bis[2-hydroxyethyl]-2aminoethanesulphonic acid, Sigma; $280 \mathrm{mM} \mathrm{NaCl}$; $1.5 \mathrm{mM} \mathrm{Na}_{2} \mathrm{HPO}_{4}$; pH 6.95) - was added in a drop-wise 
fashion. The mixture was allowed to incubate at room temperature for 15-30 min. Medium was removed from the cells and $2 \mathrm{ml}$ of DEAE dextran (Sigma) $500 \mathrm{mg} / \mathrm{ml}$ in Tris-buffered saline (TBS: $\mathrm{NaCl} 0.85 \%$, $0.25 \mathrm{M}$ Tris, $\mathrm{pH}$ 7.4) were added and incubated for $2 \mathrm{~min}$ at room temperature. The DEAE was removed by aspiration, and the DNA mixture was brought up to $3 \mathrm{ml}$ with DMEM and added to the flasks. The cells were incubated for $4-5 \mathrm{~h}$ at $37^{\circ} \mathrm{C}$ in air with $\mathrm{CO}_{2} 5 \%$. The medium was removed and cells were subjected to glycerol shock for $2 \mathrm{~min}$ ( $2 \mathrm{ml}$ of glycerol $15 \%$ in TBS). Cells were washed with TBS, $5.0 \mathrm{ml}$ of fresh medium were added and they were incubated for $40 \mathrm{~h}$ at $37^{\circ} \mathrm{C}$ in $\mathrm{CO}_{2} 5 \%$.

\section{Indirect immunofluorescence assays (IFA)}

The IFA was conducted on transfected Vero cells $48 \mathrm{~h}$ after transfection or Vero cells infected with HSV-1. For transfection, Vero cells were seeded on coverslips in 24-well plates and transfected with DNA $2 \mu \mathrm{g} /$ coverslip as described above. Vero cells were infected with the virus at a multiplicity of infection (m.o.i.) of $2 ; 24 \mathrm{~h}$ after infection, cells were harvested by gently tapping the sides of the flask thereby allowing the cells to become suspended in the medium. The cells were washed three times in PBS, pelleted by centrifugation at $1000 \mathrm{rpm}$ for $5 \mathrm{~min}$ and placed in individual wells on 12-well teflon-coated glass slides. The slides were allowed to dry, cells were fixed with methanol for $30 \mathrm{~min}$, blocked for $30 \mathrm{~min}$ with goat serum $10 \%$ in phosphate-buffered saline (PBS) at room temperature in a humidified chamber, and then incubated for $1 \mathrm{~h}$ with primary antibodies. After three washes with PBS, fluorescein-conjugated goat anti-mouse IgG (H\&L chains, Organon Teknika-Cappel, Durham, NC, USA) was added at a 1 in 40 dilution in blocking buffer. The slides were incubated for $1 \mathrm{~h}$, counterstained with Evans Blue $0.01 \%$, washed, dried, mounted and examined with a Zeiss microscope equipped with a halogen source and epifluorescence illuminator.

\section{Radiolabelling and immunoprecipitation}

Confluent Vero cell monolayers were infected at an m.o.i. of 2. Infected cells were labelled with $\left[{ }^{35} \mathrm{~S}\right]-$ methionine, $50 \mu \mathrm{Ci} / \mathrm{ml}$ of methionine-free medium, for 6-24 h after infection [32]. After labelling, cells were washed three times with PBS and pelleted by centrifugation. Proteins were extracted from radiolabelled cells with Nonidet P-40 1\% and sodium deoxycholate $0.5 \%$ in lysis buffer $(50 \mathrm{mM}$ Tris-buffer, $50 \mathrm{mM} \mathrm{NaCl}$, phenylmethyl-sulphonyl fluoride $100 \mu \mathrm{g} / \mathrm{ml}$, aprotinin $10 \mu \mathrm{g} / \mathrm{ml}$ ) and stored at $-20^{\circ} \mathrm{C}$ until used. The cell lysates from either transfection or infection experiments were mixed with mouse serum from animals immunised with $\mathrm{gB}$ or $\mathrm{gD}$ plasmids or with MAbs against $\mathrm{gB}$ and $\mathrm{gD}$ generated in this laboratory for $1 \mathrm{~h}$ at $4^{\circ} \mathrm{C}$ and rocked continuously. Protein A-Sepharose $(5 \mu \mathrm{g})$ in $200 \mathrm{ml}$ of lysis buffer was then added to the mixtures and incubated for $1.5 \mathrm{~h}$ at $4^{\circ} \mathrm{C}$ under similar conditions. The sepharose beads were washed three times with lysis buffer. Samples were then placed in electrophoresis loading buffer (SDS 2\%, 2-mercaptoethanol 4\%, $50 \mathrm{mM}$ Tris, $\mathrm{pH} 8$, bromophenol blue $0.0005 \%$ ), boiled for $5 \mathrm{~min}$ and electrophoresed in SDS-polyacrylamide gels [32].

\section{Genetic immunisation of mice}

Mice (five animals per group) were immunised with plasmids containing HSV-1 gB or gD. Plasmid DNA $(50 \mu \mathrm{g})$, alone or mixed with copolymers, was introduced into each animal either i.m. or i.p. All inoculations were performed with a $1-\mathrm{ml}$ syringe and a 25 -gauge needle in a total volume of $200 \mu \mathrm{l}$. Animals were given booster immunisations twice at 3-4 week intervals. Three weeks after the last boost, the animals were bled and antibody responses against $\mathrm{gB}$ and $\mathrm{gD}$ were evaluated by immunofluorescence and radioimmunoprecipitation (RIP) assays. Two control groups of mice were immunised with $1 \times 10^{5} \mathrm{HSV}-1$ (KOS) virus and vector plasmid DNA containing no insert, respectively.

\section{Infection of mice by scarification}

A location on the back of hairless mice or BALB/c mice between the third and fourth lumbar vertebrae, shaved with a hair-clipper, was scarified with a blunted 18-gauge needle (six scratches) giving a cross-hatch pattern. The scarified area was $c .1 \mathrm{~cm}$ in diameter and $20 \mu \mathrm{l}$ of HSV-1 (ABGK-1) virus stock containing $c$. $2.5 \times 10^{4}$ plaque-forming units (pfu) were applied to it with a pipettor and rubbed with the side of the tip. Each treatment group contained five animals. The degree of infection in mice was readily scored by mortality rates and estimating the severity and extent of the lesion on a scale 0-4. Animals were examined daily for mortality and development of lesions.

\section{Results}

\section{Transient expression of $g B$ and $g D$ in Vero cells}

To confirm the expression of the recombinant plasmids carrying the $\mathrm{gB}$ and $\mathrm{gD}$ genes, Vero cells were transfected with the corresponding plasmids and their glycoprotein expressions were detected by IFA with MAbs to $\mathrm{gB}$ and $\mathrm{gD}$. Up to $10 \%$ of the transfected cells expressed $\mathrm{gB}$ and $\mathrm{gD}$ throughout their cytoplasm (Fig. $1)$.

\section{Assessment of antibodies in mice immunised with the $g B$ or $g D$ genes}

Blood from individual mice inoculated with $\mathrm{gB}$ or $\mathrm{gD}$ plasmid with or without non-ionic block copolymers via the i.m. or i.p. routes were collected 3 weeks after the final immunisation. IFA and immunoprecipitation 

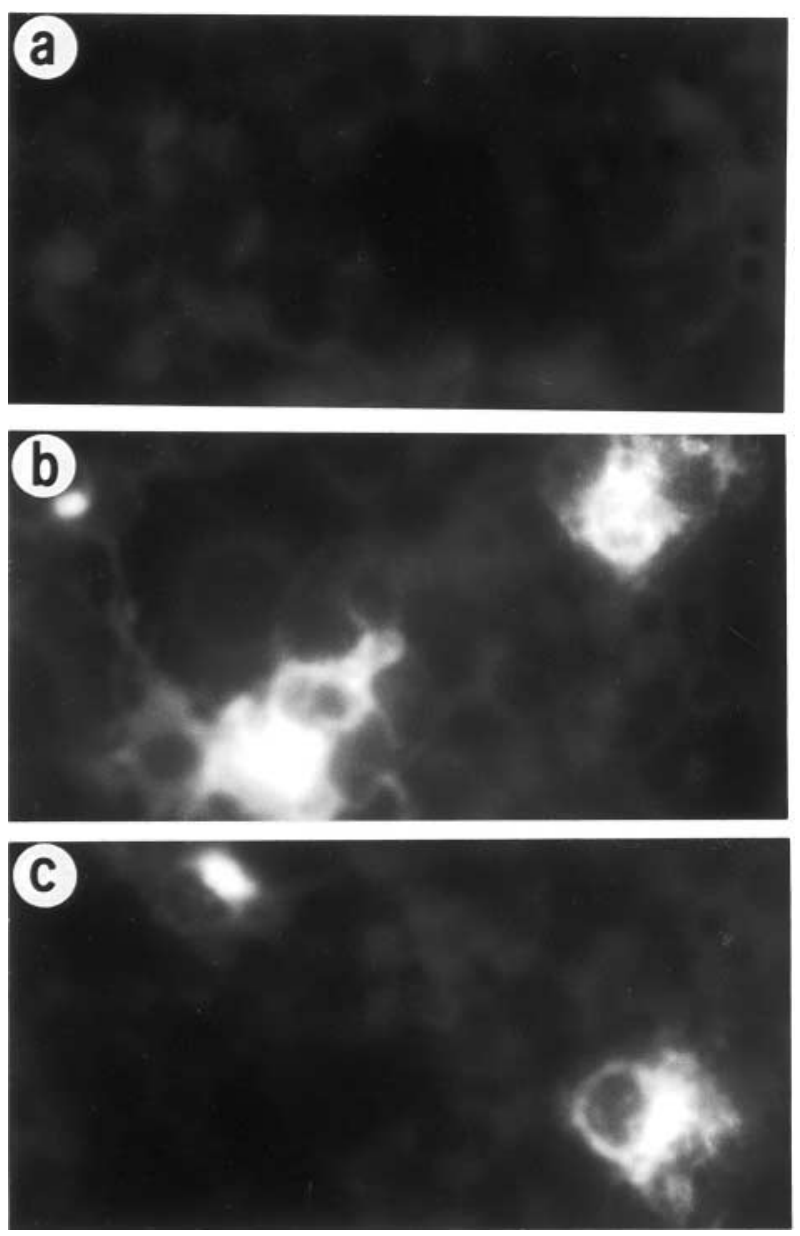

Fig. 1. Expression of $\mathrm{gB}$ and $\mathrm{gD}$ in Vero cells. Vero cells seeded on coverslips were transfected with plasmids containing $\mathrm{gB}$ or $\mathrm{gD}$ and MAbs to $\mathrm{gB}$ and $\mathrm{gD}$ were used to detect the expression of the plasmids. (a) Reaction of combined MAbs to $\mathrm{gB}$ and $\mathrm{gD}$ with mock transfected cells (plasmid without insert); (b) Vero cells transfected with plasmid containing $\mathrm{gB}$ and treated with anti-gB MAb; (c) Vero cells transfected with plasmid containing $\mathrm{gD}$ and treated with anti-gD MAb. assays with HSV-1-infected Vero cells or their ${ }^{35} \mathrm{~S}$ labelled extracts were used to assess the reactivity of the sera against their respective antigens. Four of five mice inoculated with $50 \mu \mathrm{g}$ of $\mathrm{gD}$ plasmid alone or $\mathrm{gD}$ plasmid mixed with CRL 1029 generated high anti-gD antibody responses. Similarly, all five mice inoculated with the mixture of $\mathrm{gD}$ plasmid and CRL 1190 produced high levels of anti-gD antibodies. In contrast, i.p. injections of either $\mathrm{gD}$ and CRL 1029, or $\mathrm{gD}$ and CRL 1190 did not induce any detectable antibody responses (Fig. 2). Similar experiments were performed with the gB-expressing plasmid. When gB immunisations were performed via the i.m. route, all three mice inoculated with the $\mathrm{gB}$ plasmid alone developed high levels of anti-gB antibodies. Similarly, all five mice inoculated with a mixture of $\mathrm{gB}$ and poloxamer 1029 generated high levels of gB-specific antibodies. Mice inoculated with $\mathrm{gB}$ and poloxamer 1190 appeared to elicit slightly higher levels of anti-gB antibodies when their sera were tested by RIP (Fig. 3) followed by densitometric analysis of SDS-PAGE autoradiograms (results not shown). Mice inoculated i.p. with $\mathrm{gB}$ and poloxamer 1190 developed weak humoral immune responses against $\mathrm{gB}$, whereas mice inoculated with mixtures of $\mathrm{gB}$ and CRL 1029 did not produce any anti-gB antibody (Fig. 3). The results of antibody responses were similar in both strains of mice. Therefore, the evaluation of antibody by RIP presented in Fig. 3 pertains to sera from BALB/c mice.

\section{Protection of vaccinated hairless mice against lethal challenge with HSV-1}

Vaccinated mice were challenged with the clinical isolate ABGK-1 and the course of infection was monitored at c. 12-h intervals. Initial lesions were

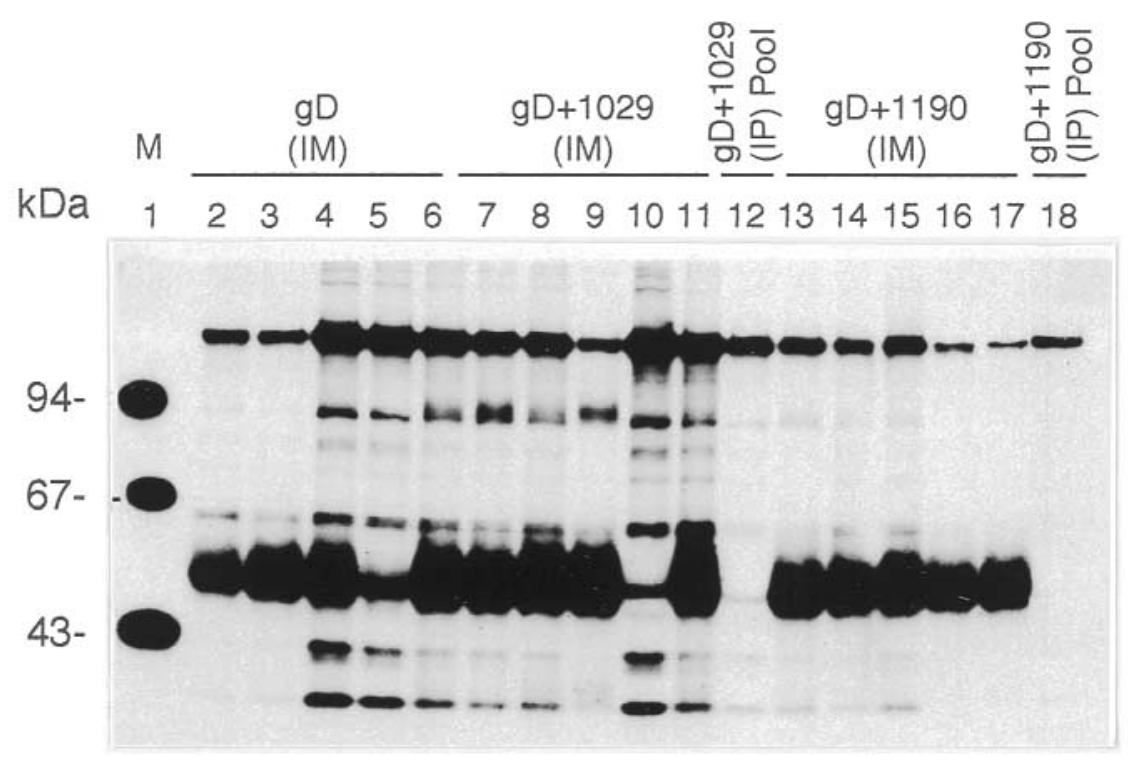

Fig. 2. Assessment of humoral immune responses against gD by RIP. Vero cells were infected with HSV-1 (KOS) at m.o.i. of 2 and labelled with ${ }^{35} \mathrm{~S}$-methionine from 6 to $24 \mathrm{~h}$ after infection. Cell lysates were mixed with individual or pooled sera from mice immunised with plasmid containing gD. The protein A-sepharose-precipitated proteins were separated electrophoretically in SDSpolyacrylamide $10 \% \mathrm{gel}$ and processed for autoradiography. Identification of lanes is displayed on top of each lane. 


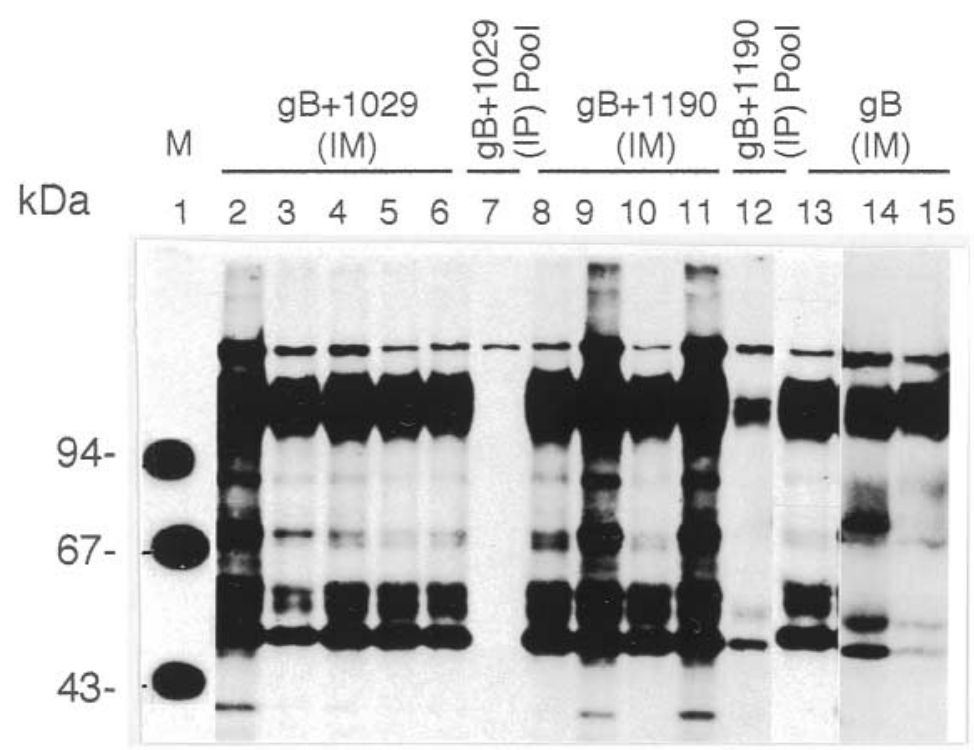

Fig. 3. Assessment of humoral immune responses against $\mathrm{gB}$ by RIP. Vero cells were infected with HSV-1 (KOS) at m.o.i. of 2 and labelled with ${ }^{35} \mathrm{~S}$-methionine from 6 to $24 \mathrm{~h}$ after infection. Cell lysates were mixed with individual or pooled sera from mice immunised with plasmid containing gB. The protein A-sepharose-precipitated proteins were separated electrophoretically in SDSpolyacrylamide $10 \%$ gel and processed for autoradiography. Identification of lanes is displayed on top of each lane.

punctate and progressed to form erosions in the area of the dermatome. These lesions enlarged within 3-10 days and at later stages of the infection formed unilateral band-like lesions which subsequently ulcerated. In animals that recovered, lesions healed within 2-3 weeks. In most cases, unprotected animals developed paralysis of the lower legs, which preceded systemic infection and death. Four of five mice in a control group, which was mock-vaccinated (naive mice), developed lesions and were initially paralysed 7-14 days after infection, followed by death. The fifth mouse developed lesions at day 13 and died 21 days after infection. Ultimately, none of these mice survived the HSV-1 infection (Fig. 4 and Table 1). In the group immunised i.m. with gD plasmid alone (four mice), one mouse developed lesions 12 days after infection and died 2 days later. Two of the remaining three mice developed small lesions which healed later (Fig. 4 and Table 1). None of the four mice immunised i.m. with gD plasmid mixed with either CRL 1029 or CRL 1190 developed lesions and they all survived the HSV-1 lethal challenge infection. A control group of mice was immunised by inoculation i.p. with $5 \times 10^{4} \mathrm{pfu}$ of HSV-1 KOS strain/mouse 2 months before the skin infection. Animals in this group developed small lesions, which ultimately healed, and all animals survived the infection (Fig. 4 and Table 1).

\section{Protection of vaccinated BALB/c mice against lethal challenge with HSV-1}

None of the animals in the mock-immunised control group survived the HSV-1 challenge (Fig. 4 and Table 2 ). A second control group of mice was immunised by inoculation i.p. of $5 \times 10^{4}$ pfu of HSV-1 KOS strain/ mouse 2 months before the skin infection. All animals in this group survived the infection; however, all developed small lesions which later healed. All the mice in groups which were vaccinated i.m. with $\mathrm{gD}$ alone or gD mixed with the copolymers CRL 1029 and 1190 were protected against the lethal challenge with HSV-1 (Fig. 4 and Table 2). All of the mice immunised with $\mathrm{gD}$ alone by i.p. injection succumbed to the lethal challenge (Table 2). However, two mice immunised with gD plasmid mixed with CRL 1029 by i.p. injection developed small lesions which resolved later and the mice survived (Table 2). Of the remaining mice, two died 9 days after infection and one mouse died 15 days after infection (Table 2). Mice immunised by i.m. injection with $\mathrm{gB}$ alone or $\mathrm{gB}$ mixed with either CRL 1029 or CRL 1190 were all protected and survived the HSV-1 challenge, although mice vaccinated with gB mixed with CRL 1190 developed lesions which later resolved (Fig. 4 and Table 2). However, vaccination by i.p. injection was not as effective. One of five mice immunised i.p. with $\mathrm{gD}$ plasmid mixed with CRL 1190 developed a limited lesion which later resolved and the mouse survived the infection. Of the remaining four mice, three mice died at 10 days and one mouse died 14 days after infection (Table 2). None of the mice immunised with $\mathrm{gB}$ plasmid alone by i.p. injection survived the infection. In contrast, three of four mice immunised i.p. with $\mathrm{gB}$ mixed with $\mathrm{CRL}$ 1190 survived the infection (Table 2).

\section{Discussion}

The results of this study show that DNA-based vaccines consisting of plasmids capable of expressing HSV-1 glycoproteins $\mathrm{gB}$ and $\mathrm{gD}$ induced strong immune responses that protected mice against lethal challenge with HSV-1. Furthermore, non-ionic block copolymers seemed to enhance humoral and protective 

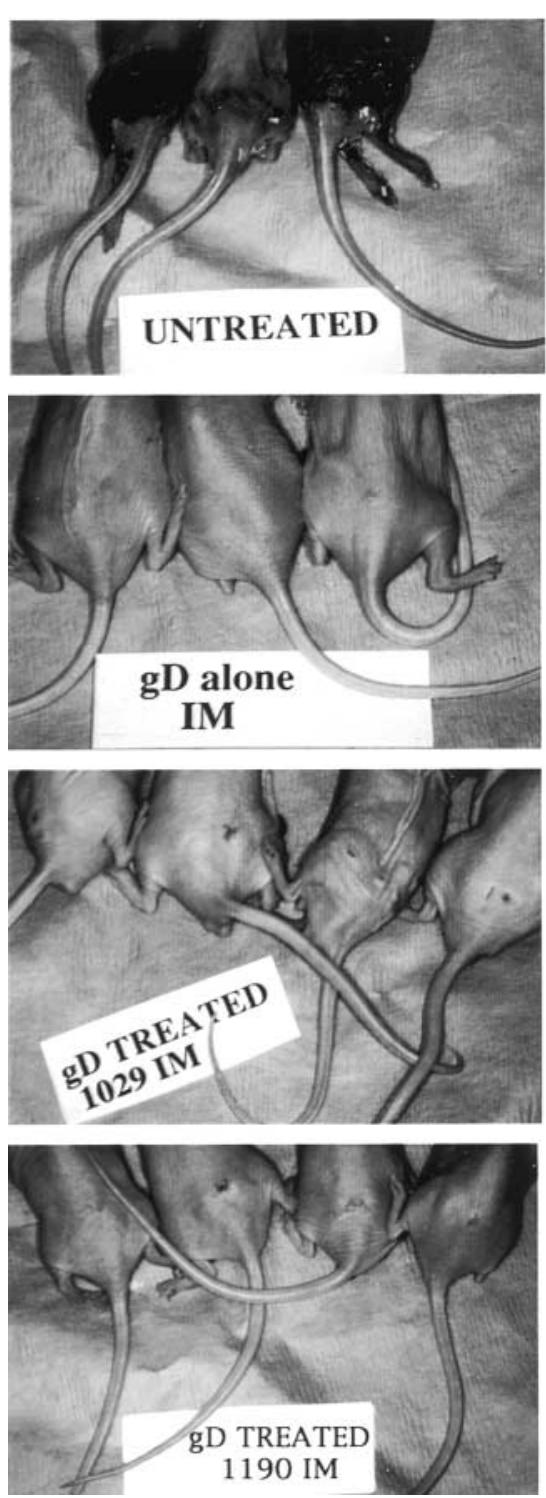
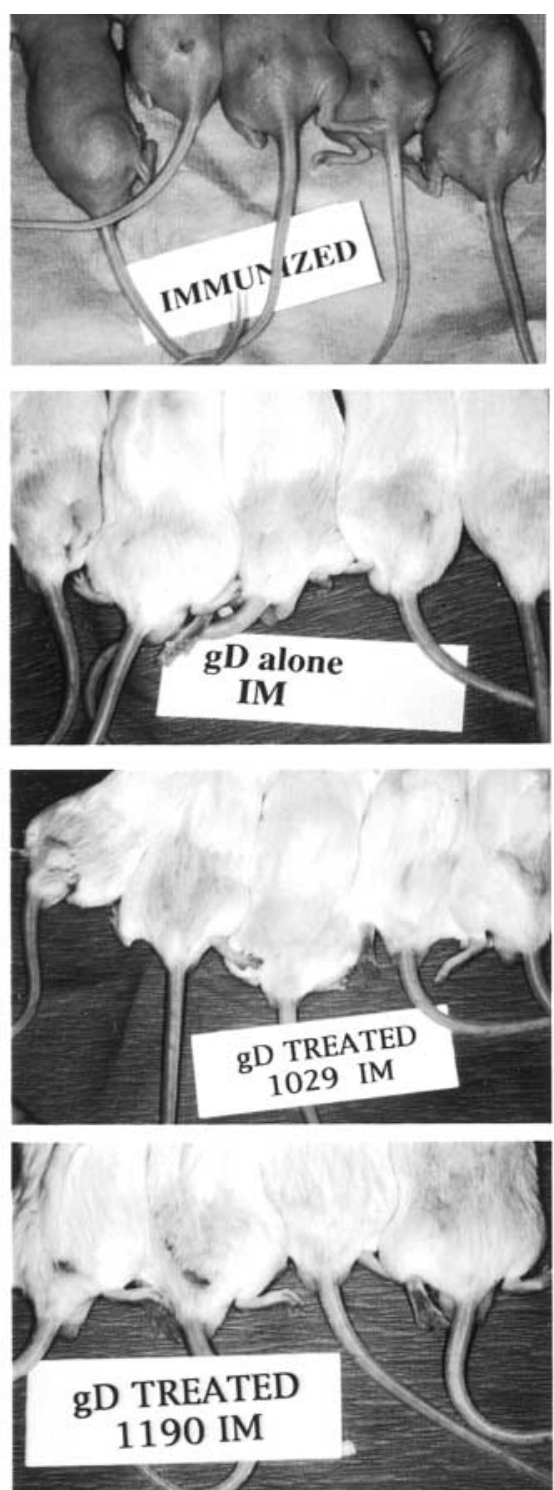
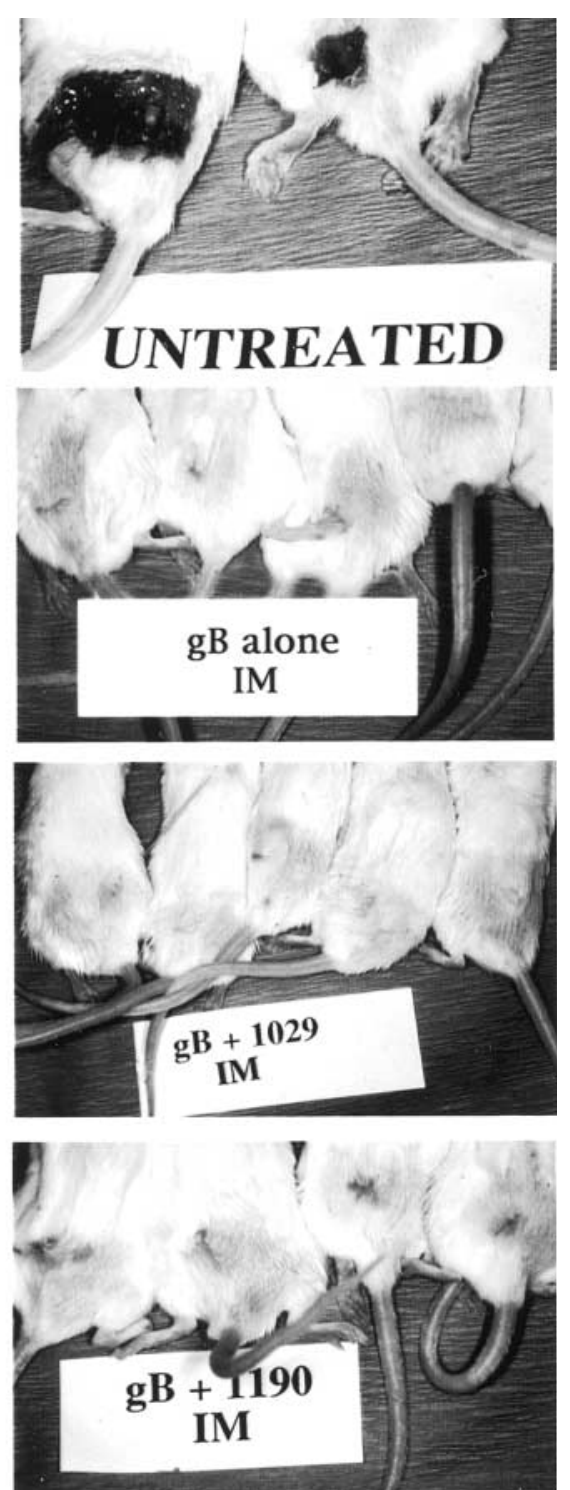

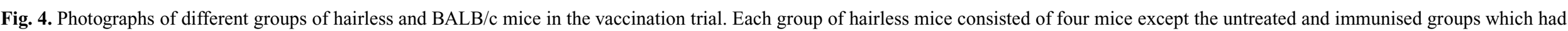

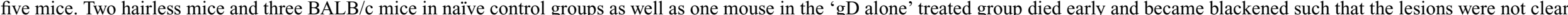
in the photographs; therefore, they were excluded from the photographs. 
Table 1. HSV-1 lethal challenge of immunised hairless mice

\begin{tabular}{lll}
\hline Experimental groups & Route & $\begin{array}{l}\text { Survived } / \text { dead } \\
(\% \text { protection })\end{array}$ \\
\hline Naive control & $\ldots$ & $0 / 5(0)$ \\
HSV-1 immunised & i.p. & $5 / 5(100)$ \\
gD alone & i.m. & $3 / 4(75)$ \\
gD plus 1029 & i.m. & $5 / 5(100)$ \\
gD plus 1190 & i.m. & $5 / 5(100)$ \\
\hline
\end{tabular}

immune responses generated by $\mathrm{gB}$ and $\mathrm{gD}$ plasmidbased vaccines when given by i.p. injection.

Gene vaccination of BALB/c and SKH-1 mice with the $\mathrm{gB}$ and $\mathrm{gD}$ genes induced high levels of antibody responses against $\mathrm{gB}$ and $\mathrm{gD}$. Furthermore, the induction of humoral responses was dependent on the route of immunisation. Generally, the i.m. route of DNA vaccination consistently produced higher levels of humoral responses than the i.p. route. These responses protected mice from lethal challenge with HSV-1 via skin scarification, which resembles the zosteriform model and is different from a previous study, where the challenge was given by systemic injection (i.p.) of an HSV-2 strain [25]. It is possible that the high amounts of plasmid DNA used in the present study produced maximum levels of humoral responses to $\mathrm{gB}$ and $\mathrm{gD}$ in the absence of poloxamers and, therefore, obscured poloxamer-mediated enhancement of humoral responses. It is worth noting that higher levels of humoral immunity and protection were produced in this study than in similar experiments by other investigators, in which gB gene was studied and only $80 \%$ of the mice immunised with the gB-expressing plasmid survived a lethal HSV-1 challenge [35]. Other studies showed that DNA vaccination with HSV-1 or HSV-2 gB or gD genes protected mice or guinea-pigs against systemic or vaginal infections, respectively $[6,7,25,26]$. This study, for the first time, showed that both $\mathrm{gB}$ and $\mathrm{gD}$ genes protected the mice against a zosteriform infection in a mouse model and the BALB/ $c$ mouse was as good a model as the hairless mouse for formation of zosteriform lesions.

Table 2. HSV-1 lethal challenge of immunised BALB/c mice

\begin{tabular}{llc}
\hline Experimental groups & Route & $\begin{array}{l}\text { Survived } / \text { dead } \\
(\% \text { protection })\end{array}$ \\
\hline Naive control & $\ldots$ & $0 / 5(0)$ \\
HSV-1 immunised & i.p. & $5 / 5(100)$ \\
gD alone & i.p. & $0 / 5(0)$ \\
gD plus 1029 & i.p. & $2 / 5(40)$ \\
gD plus 1190 & i.p. & $1 / 5(20)$ \\
gD alone & i.m. & $5 / 5(100)$ \\
gD plus 1029 & i.m. & $5 / 5(100)$ \\
gD plus 1190 & i.m. & $4 / 4(100)$ \\
gB alone & i.p. & $0 / 5(0)$ \\
gB plus 1190 & i.p. & $3 / 5(60)$ \\
gB alone & i.m. & $5 / 5(100)$ \\
gB plus 1029 & i.m. & $5 / 5(100)$ \\
gB plus 1190 & i.m. & $4 / 4(100)$ \\
\hline
\end{tabular}

The results also showed that, contrary to the i.m. route with high protection efficiency, introduction of $\mathrm{gB}$ or $\mathrm{gD}$ plasmid alone by i.p. injection did not protect the animals against the HSV-1 challenge. This failure to elicit immune responses by i.p. injection correlated with the absence of antibody production against $\mathrm{gB}$ or $\mathrm{gD}$. By contrast, co-administration of $\mathrm{gB}$ or $\mathrm{gD}$ plasmids with copolymers by i.p. injection provided some protection against lethal herpes infection, which was consistent with the ability of these mixtures to elicit humoral immune responses. It can be suggested that copolymers, by binding to the DNA, may facilitate its uptake by the resident macrophages where it can be expressed and be presented to the immune system for elicitation of protective cellular and humoral immune responses.

Genetic immunisation with a combination of HSV genes, such as those of $\mathrm{gB}$ and $\mathrm{gD}$, will produce an effective vaccine alternative to other available methods. Protection of vaccinated mice against HSV-1 challenge was $100 \%$ with either $\mathrm{gB}$ or $\mathrm{gD}$. Moreover, further study is needed to document if lower amounts of DNA in combination with non-ionic block copolymers would enhance the efficacy of DNA-based vaccination.

\section{References}

1. Whitley ME, Gnann JWJ. The epidemiology and clinical manifestations of herpes simplex virus infections. In: Roizman B, Whitley RJ, Lopez C (eds) The human herpesviruses. New York, Raven Press. 1993: 69-106.

2. Redfield RR, Wright DC, James WD, Jones TSC, Brown B, Burke DS. Disseminated vaccinia in a military recruit with human immunodeficiency virus (HIV) disease. $N$ Engl $J$ Med 1987; 316: 673-676.

3. Spear PG. Entry of alphaherpesviruses into cells. Semin Virol 1993; 4: $167-180$

4. Spear PG. Membrane fusion induced by herpes simplex virus. In: Bentz J (ed) Viral fusion mechanisms. Boca Raton, CRC Press. 1993: 201-232.

5. Roizman B, Sears AE. Herpes simplex viruses and their replication. In: Fields BN, Knipe DM, Howley PM (eds) Fields virology, 3rd edn, vol 2. Philadelphia, Lippincott-Raven. 1996: 2231-2295.

6. Ghiasi H, Nesburn AB, Kaiwar R, Wechsler SL. Immunoselection of recombinant baculoviruses expressing high levels of biologically active herpes simplex virus type 1 glycoprotein D. Arch Virol 1991; 121: 163-178.

7. Ghiasi H, Kaiwar R, Nesburn AB, Wechsler SL. Expression of herpes simplex virus type 1 glycoprotein $\mathrm{B}$ in insect cells. Initial analysis of its biochemical and immunological properties. Virus Res 1992; 22: 25-39.

8. Mishkin EM, Fahey JR, Kino Y, Klein RJ, Abramovitz AS, Mento SJ. Native herpes simplex virus glycoprotein D vaccine: immunogenicity and protection in animal models. Vaccine 1991; 9: 147-153.

9. Chan WL, Lukig ML, Liew FY. Helper T cells induced by an immunopurified herpes simplex virus type I (HSV-I) 115 kilodalton glycoprotein $(\mathrm{gB})$ protect mice against HSV-I infection. J Exp Med 1985; 162: 1304-1318.

10. Berman PW, Gregory T, Crase D, Lasky LA. Protection from genital herpes simplex virus type 2 infection by vaccination with cloned type 1 glycoprotein D. Science 1985; 227: 1490-1492.

11. Burke RL. Development of a herpes simplex virus subunit glycoprotein vaccine for prophylactic and therapeutic use. Rev Infect Dis 1991; 11 Suppl 13: S906-S911.

12. Manservigi R, Grossi MP, Gualandri R et al. Protection from 
herpes simplex virus type 1 lethal and latent infections by secreted recombinant glycoprotein B constitutively expressed in human cells with a BK virus episomal vector. J Virol 1990; 64: $431-436$.

13. Straus SE, Corey L, Burke RL et al. Placebo-controlled trial of vaccination with recombinant glycoprotein $\mathrm{D}$ of herpes simplex virus type 2 for immunotherapy of genital herpes. Lancet 1994; 343: 1460-1463.

14. Wolff JA, Malone RW, Williams $\mathrm{P}$ et al. Direct gene transfer into mouse muscle in vivo. Science 1990; 247: 1465-1468.

15. Wang B, Boyer J, Srikantan V et al. DNA inoculation induces neutralizing immune responses against human immunodeficiency virus type 1 in mice and nonhuman primates. DNA Cell Biol 1993; 12: 799-805.

16. Vahlsing HL, Yankauckas MA, Sawdey M, Gromkowski SH, Manthorpe M. Immunization with plasmid DNA using a pneumatic gun. J Immunol Methods 1994; 175: 11-22.

17. Cox GM, Zamb TJ, Babiuk LA. Bovine herpesvirus 1: immune responses in mice and cattle injected with plasmid DNA. J Virol 1993; 67: 5664-5667.

18. Robinson HL, Hunt LA, Webster FG. Protection against a lethal influenza virus challenge by immunization with a haemagglutinin-expressing plasmid DNA. Vaccine 1993; 11: 957-960.

19. Montgomery DL, Shiver JW, Leander KR et al. Heterologous and homologous protection against influenza $\mathrm{A}$ by DNA vaccination: optimization of DNA vectors. DNA Cell Biol 1993; 12: $777-783$.

20. Ulmer JB, Donnelly JJ, Parker SE et al. Heterologous protection against influenza by injection of DNA encoding a viral protein. Science 1993; 259: 1745-1749.

21. Xiang ZQ, Spitalnik SL, Cheng J, Erikson J, Wojczyk B, Ertl HCJ. Immune responses to nucleic acid vaccines to rabies virus. Virology 1995; 209: 569-579.

22. Davis HL, Michel M-L, Whalen RG. DNA-based immunization induces continuous secretion of hepatitis B surface antigen and high levels of circulating antibody. Hum Mol Genet 1993; 2: $1847-1851$.

23. Gardner MJ, Doolan DL, Hedstrom RC et al. DNA vaccines against malaria: immunogenicity and protection in a rodent model. J Pharm Sci 1996; 85: 1294-1300.

24. Kuklin N, Daheshia M, Karem K, Manickan E, Rouse BT. Introduction of mucosal immunity against herpes simplex virus by plasmid DNA immunization. J Virol 1997; 71: 3138-3145.
25. McClements WL, Armstrong ME, Keys RD, Liu MA Immunization with DNA vaccines encoding glycoprotein D or glycoprotein $\mathrm{B}$, alone or in combination, induces protective immunity in animal models of herpes simplex virus-2 disease. Proc Natl Acad Sci USA 1996; 93: 11414-11420.

26. McClements WL, Armstrong ME, Keys RD, Liu MA. The prophylactic effect of immunization with DNA encoding herpes simplex virus glycoproteins on HSV-induced disease in guinea pigs. Vaccine 1997; 15: 857-860.

27. Ruitenberg KM, Walker C, Wellington JE, Love DN, Whalley JM. DNA-mediated immunization with glycoprotein D of equine herpesvirus 1 (EHV-1) in a murine model of EHV-1 respiratory infection. Vaccine 1999; 17: 237-244.

28. Jiang C, Magee DM, Quitugua TN, Cox RA. Genetic vaccination against Coccidioides immitis: comparison of vaccine efficacy of recombinant antigen 2 and antigen 2 cDNA. Infect Immun 1999; 67: 630-635.

29. Newman MJ, Todd CW, Balasubramanian M. Design and development of adjuvant-active nonionic block copolymers. J Pharm Sci 1998; 87: 1357-1362.

30. Newman MJ, Actor JK, Balusubramanian M, Jagannath C. Use of nonionic block copolymers in vaccines and therapeutics. Critical Reviews in Therapeutic Drug Carrier Systems, vol 15, Begell House. 1998: 89-142.

31. Newman MJ, Todd CW, Lee EM, Balusubramanian M, Didier PJ, Katz JM. Increasing the immunogenicity of a trivalent influenza virus vaccine with adjuvant-active nonionic block copolymers for potential use in the elderly. Mech Ageing Dev 1997; 93: 189-203.

32. Baghian A, Huang L, Newman S, Jayachandra S, Kousoulas KG. Truncation of the carboxy-terminal 28 amino acids of glycoprotein B specified by herpes simplex virus type 1 mutant amb1511-7 causes extensive cell fusion. J Virol 1993; 67: 2396-2401.

33. Mathews JT, Cohen GH and Eisenberg RJ. Synthesis and processing of glycoprotein D of herpes simplex virus types 1 and 2 in an in vitro system. J Virol 1983; 48: 521-533.

34. Chen C, Okayama H. High-efficiency transformation of mammalian cells by plasmid DNA. Mol Cell Biol 1987; 7: $2745-2752$.

35. Manickan E, Rouse RJD, Yu Z, Wire WS, Rouse BT. Genetic immunization against herpes simplex virus. Protection is mediated by CD4+ T lymphocytes. J Immunol 1995; 155: 259-265. 